\title{
Effects of hypoxia inducible factor-1a on apoptotic inhibition and glucocorticoid receptor downregulation by dexamethasone in AtT-20 cells
}

Chenran Zhang ${ }^{1 \dagger}$, Qiang Qiang ${ }^{2+}$, Ying Jiang ${ }^{1+}$, Liuhua $\mathrm{Hu}^{3^{*}}$, Xuehua Ding ${ }^{1}$, Yicheng Lu ${ }^{1}$ and Guohan $\mathrm{Hu}^{1 *}$

\begin{abstract}
Background: Hypoxia inducible factor-1a (HIF-1a) is the central transcriptional regulator of hypoxic responses during the progression of pituitary adenomas. Although previous immunohistochemical studies revealed that HIF-1a is expressed in adreno-cortico-tropic-hormone (ACTH) pituitary adenomas, the role of HIF-1a remains unclear.

Methods: AtT-20 cells were incubated under hypoxic conditions $\left(1 \% \mathrm{O}_{2}\right)$ for $12 \mathrm{~h}$. HIF-1a mRNA and protein expression levels were measured by real-time PCR and western blotting, respectively. BrdU was used to determine the effects of hypoxia on cell viability. AtT-20 cells were transfected with siRNA targeting HIF-1a, followed by hypoxia (1 \% $\mathrm{O}_{2}$ ) for $12 \mathrm{~h}$. Apoptosis was determined by annexin V-FITC flow cytometry and Tdt-mediated dUTP nick end-labelling (TUNEL) assay. In addition, we examined interactions between HIF-1a, glucocorticoid receptor (GR), and dexamethasone under both normoxic and hypoxic conditions.

Results: Hypoxia triggered the time-dependent proliferation of AtT-20 cells in association with increased HIF-1a mRNA and protein levels. However, the viability of AtT-20 cells decreased greatly when they were first transfected with HIF-1a-siRNA and then exposed to hypoxia. According to flow cytometry (annexin V-FITC and PI staining) and TUNEL analyses, a greater percentage of cells were apoptotic when transfected with HIF-1a siRNA and subsequently cultured under hypoxic conditions compared to those in the normoxia and mock groups. After AtT-20 cells were cultured in $1 \% \mathrm{O}_{2}$ and then treated with dexamethasone, HIF-1a levels significantly increased or decreased in normoxic or hypoxic conditions, respectively. Dexamethasone suppressed GR expression to a higher degree in hypoxic than normoxic conditions. Downregulation of GR by dexamethasone was greatly prevented in cells that were transfected with HIF-1 a siRNA.
\end{abstract}

Conclusions: These findings strongly suggest that HIF-1a exerts an antiapoptotic role and participates in the downregulation of GR by dexamethasone in hypoxic AtT-20 cells.

Keywords: Hypoxia inducible factor-1a, Glucocorticoid receptor, Apoptosis, Dexamethasone, ACTH pituitary adenomas

\footnotetext{
*Correspondence: iam565@126.com; huguohan@163.com

${ }^{\dagger}$ Equal contributors

${ }^{3}$ Department of Cardiology, Ren Ji Hospital, School of Medicine, Shanghai

Jiao Tong University, Shanghai 200127, China

'Department of Neurosurgery, Shanghai Changzheng Hospital, Second

Military Medical University, No. 415, Feng-Yang Road, Shanghai 200003,

China

Full list of author information is available at the end of the article
}

\section{Biomed Central}

(c) 2015 Zhang et al. This is an Open Access article distributed under the terms of the Creative Commons Attribution License (http://creativecommons.org/licenses/by/4.0), which permits unrestricted use, distribution, and reproduction in any medium, provided the original work is properly credited. The Creative Commons Public Domain Dedication waiver (http:// creativecommons.org/publicdomain/zero/1.0/) applies to the data made available in this article, unless otherwise stated. 


\section{Background}

Pituitary adenomas are less vascularised [1] and oxygenated [2] compared to the anterior and posterior lobes of the pituitary gland, in contrast to other malignant neoplasms. This phenomenon suggests that pituitary adenoma cells might acquire tolerance to hypoxia. Normally, hypoxia can induce tumour cell death [3]; however, the presence of necrotic or apoptotic changes is rarely observed in pituitary adenomas [4].

Hypoxia inducible factor- $1 \alpha$ (HIF- $1 \alpha)$ is the central transcriptional regulator of the hypoxic response. Activated HIF- $1 \alpha$ drives the transcription of more than $2 \%$ of all human genes either directly or indirectly to adjust the homeostasis of cells under hypoxic conditions [5]. A previous article reported that HIF- $1 \alpha$ is expressed in ACTH pituitary adenomas [6]. However, the roles of HIF- $1 \alpha$ in the development and clinical presentation of ACTH pituitary adenomas remain unknown.

The relationship between HIF- $1 \alpha$ and apoptosis was recently revealed [7]. It remains controversial whether hypoxia induces a pro- or antiapoptotic process [8]. Coincidently, adaptation to hypoxic environments is also influenced by glucocorticoids. There is cross-talk between hypoxiadependent signals and glucocorticoid-mediated regulation of gene expression [9-11]. However, the cross-talk between HIF- $1 \alpha$ and glucocorticoid pathways remains poorly defined.

In the present study, we employed a special hypoxia incubator $[12,13]$ and HIF-1 $\alpha$ siRNA to study the effects of HIF- $1 \alpha$ expression on the proliferation and protection from apoptosis in AtT-20 cells in vitro. We also explored the interactions of HIF-1 $1 \alpha$, glucocorticoid receptor (GR), and dexamethasone under both normoxic and hypoxic conditions.

\section{Methods}

\section{Cell culture and hypoxia induction}

AtT-20 cells were obtained from the American Type Culture Collection (Manassas, VA, USA) and routinely cultured in Ham's-F12K medium (Gibco, USA), supplemented with $2 \mathrm{mM}$ L-glutamine, $1.5 \mathrm{~g} / \mathrm{L}$ sodium bicarbonate $(82.5 \%)$, horse serum, (15\%), and foetal bovine serum (Gibco, BRL) $(2.5 \%)$ at $37{ }^{\circ} \mathrm{C}$ in a humidified atmosphere containing $5 \%$ carbon dioxide. For hypoxic exposure, cells were cultured in a specifically designed hypoxia incubator (Thermo Electron, Forma, MA) in an atmosphere consisting of $94 \% \mathrm{~N}_{2}, 5 \% \mathrm{CO}_{2}$, and $1 \% \mathrm{O}_{2}$.

\section{Reagents}

Dexamethasone and dimethyl sulfoxide (DMSO) were purchased from Sigma-Aldrich. The short-interfering RNA (siRNA) against mouse HIF- $1 \alpha$ and mock siRNA (nonsense sequence) were purchased from Santa Cruz Technology (Santa Cruz, CA). All other reagents were of the highest analytical grade available.

\section{BrdU}

Cell proliferation of AtT-20 cells in hypoxic conditions was measured by a BrdU incorporation assay. Cells under different treatments were plated onto 96-well plates. These cells were subjected to BrdU using the BrdU Cell Proliferation Kit (Cell Signaling, USA) following the manufacturer's instructions. Three independent experiments were performed. Next, we employed Multisizer 3 COULTER COUNTER to count the AtT20 cell numbers. Before counting the sample, flush the system and count PBS as a blank control. Put $0.2 \mathrm{ml}$ of suspension of cells into $10 \mathrm{ml} \mathrm{PBS}$, and then mix the sample thoroughly. Turn the glass valve directly above the cells to vertical, and then turn it back to horizontal to begin the count. The count displayed is the the number of cells in $0.5 \mathrm{ml}$.

\section{RNA extraction and real-time PCR}

RNA was prepared using the TRIzol reagent (Invitrogen, Carlsbad, CA, USA). One microgram of total RNA, $1 \mu \mathrm{L}$ oligo(dT) 15 primer (Promega, USA) and DEPC water were added to a total volume of $10 \mu \mathrm{L}$, heated to $70{ }^{\circ} \mathrm{C}$ for $5 \mathrm{~min}$, and placed on ice for $5 \mathrm{~min}$. Then a mixture of M-MLV RT $5 \times$ reaction buffer $(5 \mu \mathrm{L}), 100 \mathrm{mM}$ dNTPs $(0.5 \mu \mathrm{L}), 1 \mu \mathrm{L}$ M-MLV RT H(-) point mutant, and DEPC water in a final volume of $15 \mu \mathrm{L}$ (all from Promega, Madison, USA) was added to each sample, followed by incubation at $40^{\circ} \mathrm{C}$ for $60 \mathrm{~min}$ and $70{ }^{\circ} \mathrm{C}$ for 15 min. Real-time PCR was performed using the $\mathrm{SYBR}^{\circ}$ Premix Ex Taq ${ }^{\text {Tm }}$ PCR kit (Takara, Japan) on the Applied Biosystems 7300 Real-Time PCR System (Foster, CA, USA). The $20-\mu \mathrm{L}$ reaction of the SYBR Green assay contained $10 \mu \mathrm{L}$ of $2 \times$ SYBR Premix Ex Taq, $0.4 \mu \mathrm{L}$ PCR forward primers and $0.4 \mu \mathrm{L}$ reverse primers, $0.4 \mu \mathrm{L}$ ROX reference dye $(50 \times), 2 \mu \mathrm{L}$ cDNA, and $6.8 \mu \mathrm{L}$ doubledistilled $\mathrm{H}_{2} \mathrm{O}$. PCR was carried out as follows: one cycle of $95{ }^{\circ} \mathrm{C}$ for $10 \mathrm{~s}$ (pre-denature) and 40 cycles of two steps $\left(95{ }^{\circ} \mathrm{C}\right.$ for $5 \mathrm{~s}$ and $60{ }^{\circ} \mathrm{C}$ for $\left.31 \mathrm{~s}\right)$. At the end of the amplification, a dissociation curve (melting curve) was plotted in the temperature range $65-95{ }^{\circ} \mathrm{C}$. All amplifications and detections were carried out in a MicroAmp optical 96-well reaction plate with optical adhesive covers (Applied Biosystems). PCRs were performed in triplicate, and a reliable internal control under hypoxia, $28 \mathrm{~S}$ rRNA, was co-amplified to normalize the amount of RNA added to the reaction [14]. Normoxia group in Fig. $1 \mathrm{~b}, 1 \% \mathrm{O}_{2}-0 \mathrm{~h}$ without dexamethasone in Fig. $3 \mathrm{a}$ and $3 \mathrm{~b}, 1 \% \mathrm{O}_{2}-0 \mathrm{~h}$ in Fig. $4 \mathrm{a}$ and $4 \mathrm{~b}$ were used as calibrator for relative quantitative PCR. All data were analysed using the Applied Biosystems 7300 SDS Software (Applied Biosystems, CA, USA). $-2^{-\Delta \Delta \mathrm{ct}}$ method was used to analyze the real time PCR results.

Primer sequences were as follows: 


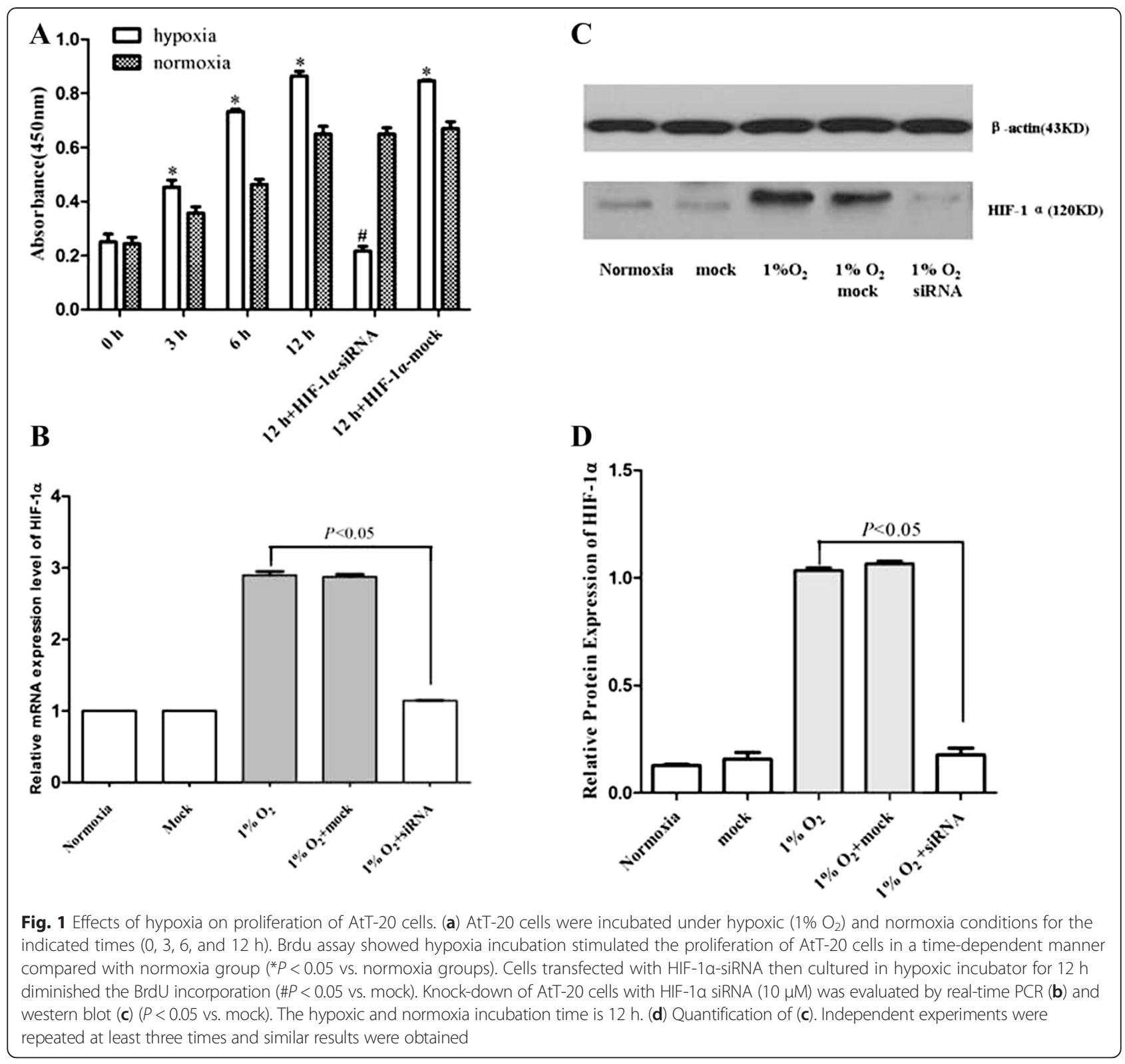

HIF-1 $\alpha$ : forward 5'-ACCTTCATCGGAAACTCCAAAG-3' reverse 5'-CTGTTAGGCTGGGAAAAGTTAGG-3'; GR: forward 5'-AAGAGACAAACGAGAGTCCTTGG-3' reverse 5'-GTGTCCGGTAAAATAAGAGGCTT-3'; 28S rRNA: forward: 5' - AATGCCTCGTCATCTAAT-3' reverse 5'- TTCGCTGGATAGTAGGTA-3'.

We designed the 28S rRNA primers online. The website was sigma.com/probedesignonline. Actually, we had searched many literatures about the $28 \mathrm{~S}$ primers of mouse, but it was difficult to find a matched one.

\section{Western blot analysis}

Cells were extracted by centrifugation at $3000 \mathrm{rpm}$ for 2 min, followed by one cold PBS wash and lysed in lysis buffer (RIPA 1:1, PMSF 100:1, and protein inhibitor 1:200). After a 30-min incubation on ice, cell lysates were centrifuged at $13000 \mathrm{rpm}$ at $4{ }^{\circ} \mathrm{C}$ for $15 \mathrm{~min}$. Total proteins were quantified by the Thermo Scientific Pierce BCA protein assay kit according to its instruction. One hundred micrograms of sample were first electrophoresed on a $7.5 \%$ SDS-polyacrylamide gel and transferred to PVDF membranes. Ponceau $\mathrm{S}$ staining was performed on the membranes to ensure successful transfer. After transfer, the membranes were blocked with $10 \%$ fat-free milk for $2 \mathrm{~h}$ at room temperature, and then incubated with either rabbit polyclonal anti-HIF- $1 \alpha$ antibody (H-206, Santa Cruz) at a 1:500 dilution at $4{ }^{\circ} \mathrm{C}$ overnight or anti-GR antibody (M-20, Santa Cruz, CA, USA) at a 1:500 dilution for $2 \mathrm{~h}$ at room temperature. After washing three times with $1 \times$ 
TBS-Tween, the membranes were then incubated for $1 \mathrm{~h}$ with anti-rabbit IgG, HRP-linked secondary antibody (HIF$1 \alpha, 1: 20,000$ or GR, 1:3000) and visualized using a chemiluminescence detection kit, ECL-PLUS (Amersham Biosciences). Anti- $\beta$-actin (mouse monoclonal, 1:20,000; Calbiochem, La Jolla, CA) was used as protein control. The relative amount of protein was quantified by densitometry using Image J software.

\section{Knock-down of HIF-1a protein expression with siRNA}

AtT-20 cells $\left(4 \times 10^{5}\right)$ were seeded into 12-well plates without antibiotics and incubated at $37{ }^{\circ} \mathrm{C}$ for $5 \mathrm{~h}$ to $90 \%$ confluence. Four microlitres of $10 \mu \mathrm{M}$ HIF- $1 \alpha$ siRNA (Santa Cruz, CA, USA) and $2 \mu \mathrm{L}$ Lipofectamine 2000 (Invitrogen, Carlsbad, CA, US) were gently mixed with $100 \mu \mathrm{L}$ siRNA transfection medium (OPTI-MEM, Gibco, $\mathrm{BRL}$, USA) for $5 \mathrm{~min}$ at room temperature, and the mixtures were then combined and incubated at room temperature for another $20 \mathrm{~min}$ to form siRNALipofectamine 2000 complexes. The complexes were finally added to the cells. After incubation at $37^{\circ} \mathrm{C}$ for $24 \mathrm{~h}$, cells were cultured with medium containing antibiotics and cultured in $1 \% \mathrm{O}_{2}$ for $12 \mathrm{~h}$. The efficiency of the HIF$1 \alpha$ knock-down by siRNA was evaluated by real-time PCR and western blot. Mock siRNA (Santa Cruz, CA) was transfected as a negative control.

\section{Annexin V-FITC detecting system}

Apoptotic cells were detected using the annexin V-FITC apoptosis detection kit (BD Biosciences Pharmingen). Cells were seeded into 24-well plates at a density of $40 \times 10^{4}$ cells per well. After a 12 -h incubation in hypoxic conditions and transfection with HIF-1 $\alpha$-siRNA, cells were washed twice with cold PBS and then resuspended in $200 \mu \mathrm{L} 1 \times$ binding buffer. One hundred microlitres of the above cell solution were transferred into a 5 -mL tube, and $5 \mu \mathrm{L}$ of annexin V-FITC and $5 \mu \mathrm{L}$ of PI were added. The tubes were gently vortexed and incubated for $15 \mathrm{~min}$ at room temperature in the dark. Four hundred microlitres of $1 \times$ binding buffer was added, and the cells were analysed by flow cytometry (BD FACS Calibur) within $1 \mathrm{~h}$. For each measurement 10000 cells were analyzed.

\section{Tunel staining}

FACS data on apoptosis was further verified using the terminal deoxynucleotidyl transferase (Tdt)-mediated dUTP nick end-labelling (TUNEL) assay. The TUNEL technique was performed using the in situ cell death detection kit (Roche Diagnostics, Indianapolis, IN, USA), according to the manufacturer's instructions. Chamber slides were fixed with $4 \%$ paraformaldehyde for $1 \mathrm{~h}$, and $0.1 \%$ Triton-100 in $0.1 \%$ sodium citrate was added at $4{ }^{\circ} \mathrm{C}$ for $2 \mathrm{~min}$. The slides were incubated with the TUNEL reaction mixture for $1 \mathrm{~h}$ at $37{ }^{\circ} \mathrm{C}$. After washing, the slides were further incubated with alkaline phosphatase-conjugated anti-fluorescein antibody for $30 \mathrm{~min}$ at $37{ }^{\circ} \mathrm{C}$. Slides were developed using Fast Red (DAKO, Carpenteria, CA, USA) and lightly counterstained with hematoxylin.TUNEL positive cells were observed under confocal microscopy. TUNEL-positive cells per field were counted in 5 random fields under $40 \times$ magnifications, and positive cell percentages were averaged.

\section{Statistical analysis}

The two tailed Student's $t$ test was used to analyse the data. Results are expressed as means \pm SEM. $P$ less than 0.05 was considered statistically significant.

\section{Results}

Hypoxia triggered the proliferation of AtT-20 cells through the induction of HIF-1a mRNA and protein expression

AtT-20 cells were incubated under hypoxic $\left(1 \% \mathrm{O}_{2}\right)$ and normoxia conditions for the indicated time points $(0,3$, 6, or $12 \mathrm{~h}$ ). As shown in Fig. 1a, the BrdU assay showed that hypoxia stimulated the proliferation of AtT-20 cells in a time-dependent manner compared with that of the normoxic group $(P<0.05)$ without any signs of cytotoxicity. Under hypoxic conditions $\left(1 \% \mathrm{O}_{2}\right)$ for $12 \mathrm{~h}$, cells transfected with mock siRNA did not show significantly reduced BrdU incorporation compared with untransfected cells. In contrast, cells transfected with HIF-1 $\alpha$ specific siRNA showed significantly diminished BrdU incorporation (Fig. 1a). AtT20 cell numbers (using a Coulter counter) were consistent with the BrdU results (data not shown). These findings were associated with the expression of HIF- $1 \alpha$ mRNA and protein, as detected by real-time PCR (Fig. 1b) and western blotting (Fig. 1c and $\mathrm{d}$ ), respectively.

\section{Role of HIF-1a in protecting AtT-20 cells from hypoxia-induced apoptosis}

To further determine possible mechanisms through which HIF- $1 \alpha$ contributes to AtT-20 cell growth and proliferation, RNA interference for HIF- $1 \alpha$ was employed by transfecting cells with a specific siRNA against mouse HIF- $1 \alpha$ mRNA. After transfecting HIF- $1 \alpha$ siRNA, an annexin VFITC apoptosis detection system was employed to determine whether HIF-1 $\alpha$ might shield AtT-20 cells from hypoxia-induced apoptosis. Multiple siRNA concentrations were tested; transfection of $10 \mu \mathrm{M}$ HIF- $1 \alpha$ siRNA for $48 \mathrm{~h}$ knocked down hypoxia-induced HIF-1 $\alpha$ mRNA and protein expression levels by more than $50 \%$. The relative mRNA expression levels of HIF- $1 \alpha$ according to realtime PCR were 1.00 under normoxic conditions and $2.867 \pm 0.3946$ in $1 \% \mathrm{O}_{2}(P<0.05)$. Relative expression of HIF-1 $\alpha$ was significantly reduced to $1.180 \pm 0.0694$ 
$(P<0.001)$ by siRNA, whereas mock transfection did not show significant changes in the relative expression of HIF-1 $\alpha$ in $1 \%$ oxygen (Fig. 1b). Western blots also showed higher expression of HIF-1 $\alpha$ under hypoxic conditions and reduced expression by siRNA (Fig. 1c and d). These experiments indicate a firm gene-silencing effect on HIF $-1 \alpha$ by siRNA at the mRNA and protein levels. Annexin V-FITC detection by flow cytometry showed increased early apoptosis when cells were transfected with HIF- $1 \alpha$ siRNA and subsequently cultured in $1 \%$ $\mathrm{O}_{2}$ for $12 \mathrm{~h}(28.90 \%$ and $10.00 \%, P<0.05)$ (Fig. 2a) compared with the normoxia and mock groups. These results were confirmed by TUNEL assay. We found that TUNEL-positive cells were weakly expressed in the normoxia and mock groups. However, a significantly greater proportion of cells transfected with siRNA targeting HIF- $1 \alpha$ mRNA and cultured in $1 \% \mathrm{O}_{2}$ were TUNEL positive (Fig. 2b).
A

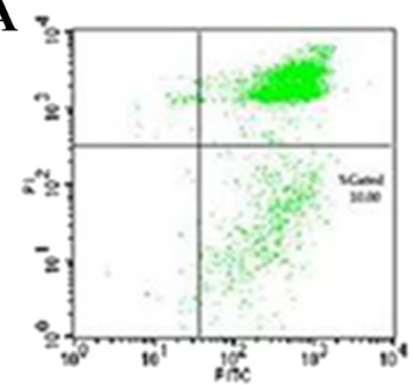

Normoxia

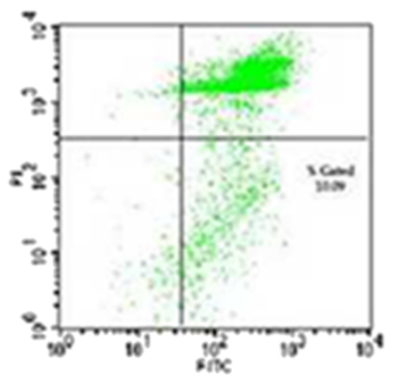

$1 \% \mathrm{O}_{2}+$ mock
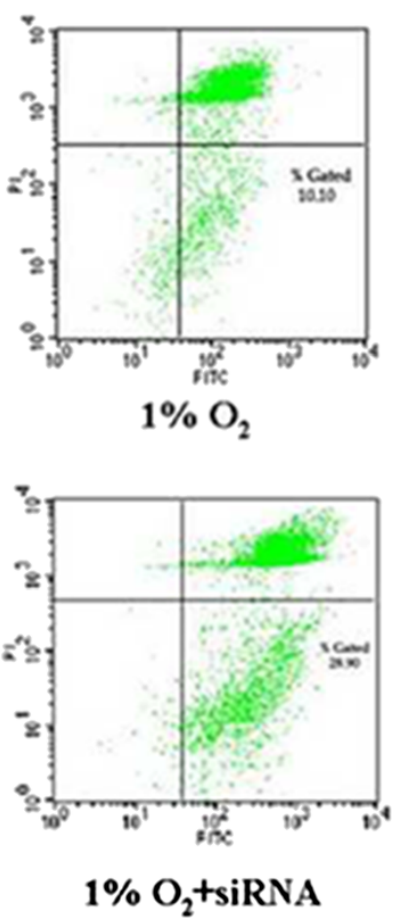

B

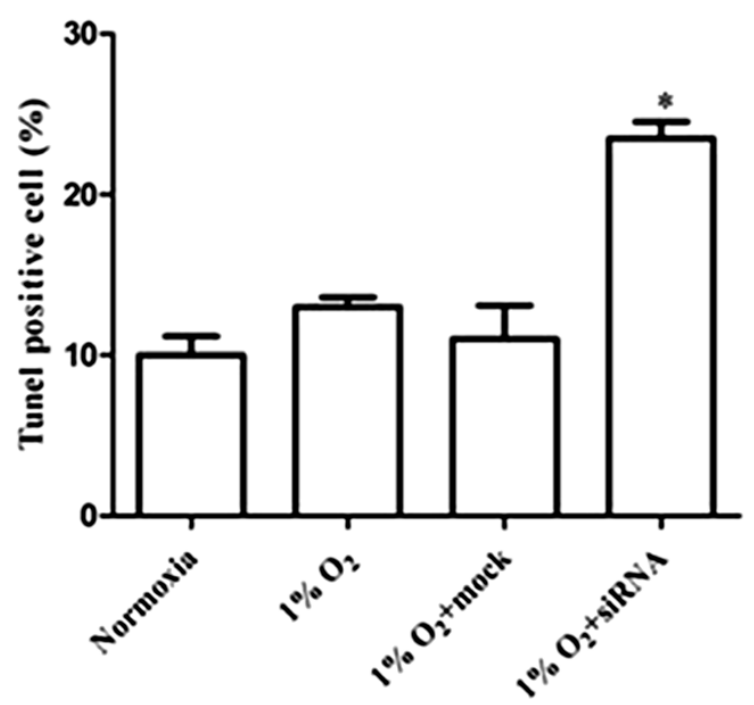

Fig. 2 Role of HIF-1a in protecting AtT-20 cells from hypoxia-induced apoptosis. AtT-20 cells were transfected with $10 \mu \mathrm{M}$ HIF-1a siRNA or mock transfected, and subsequently cultured in hypoxic or normoxic conditions for 12h. (a) Annexin V-FITC and (b) TUNEL assay showed increased apoptosis when cells were transfected with HIF-1a siRNA and subsequently cultured in $1 \% \mathrm{O}_{2}$ for $12 \mathrm{~h}$ compared with normoxia and mock groups ( ${ }^{*} P<0.05$ vs.the other groups) 
Interaction of HIF-1a, GR, and glucocorticoids: The role of HIF-1 $a$ in GR downregulation after administration of dexamethasone in hypoxic conditions

Next, we tested HIF- $1 \alpha$ and GR changes in AtT-20 cells after hypoxic incubation $(0,6,12$, and $24 \mathrm{~h})$ and dexamethasone treatment $(24 \mathrm{~h})$. Briefly, AtT-20 cells pretreated with dexamethasone (10 nM or $100 \mathrm{nM})$ for $1 \mathrm{~h}$ were first incubated under hypoxic conditions $\left(\begin{array}{lll}1 & \mathrm{O}_{2}\end{array}\right)$ for the indicated time and then under normoxic conditions for the remaining time. Under normoxic conditions, dexamethasone (10 $\mathrm{nM}$ and $100 \mathrm{nM})$ increased mRNA and protein expression levels of HIF-1 $\alpha$, but had the opposite effect after hypoxic incubation (Fig. 3a, c and $\mathrm{d}$ ). Dexamethasone suppressed HIF-1 $\alpha$ expression in a hypoxia-dependent manner. Downregulation of GR mRNA and protein by dexamethasone was more obvious under hypoxic conditions than under normoxic conditions (Fig. 3b-d).

AtT-20 cells were transfected with HIF- $1 \alpha$-siRNA and then cultured in normoxia or hypoxic incubator for $12 \mathrm{~h}$ to further clarify whether downregulation of GR by dexamethasone treatment (24h) under hypoxic conditions was HIF-1 $\alpha$ dependent. As shown in Fig. 4b-d, mRNA and protein expression levels of GR were increased in cells transfected with HIF- $1 \alpha$ siRNA and grown under hypoxic conditions compared to those of nontransfected cells after administration of dexamethasone $(P<0.05)$. In contrast, the mock transfection group exhibited no obvious changes in GR expression levels.

\section{Discussion}

In the current study, we found that hypoxic incubation $\left(1 \% \mathrm{O}_{2}\right)$ triggered the growth and proliferation of AtT20 cells through the induction of HIF- $1 \alpha$ expression at the mRNA and protein levels. Transfection of HIF-1 $\alpha$ siRNA resulted in the death of most cells. Furthermore, we performed an annexin V-FITC assay to detect early apoptosis and a TUNEL assay to determine the antiapoptotic role of HIF- $1 \alpha$ in AtT-20 cells. A greater percentage of cells transfected with HIF-1 $\alpha$ siRNA underwent

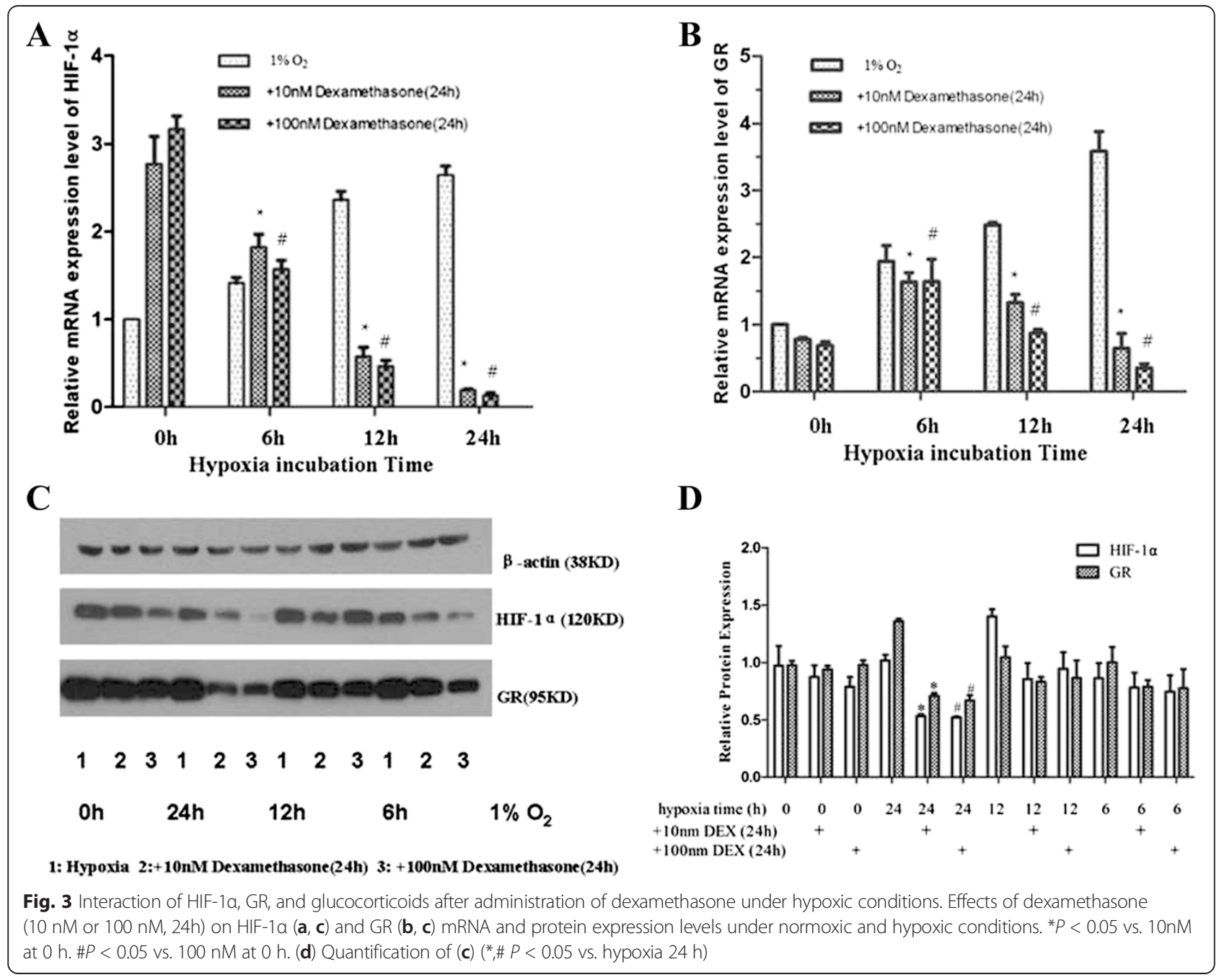




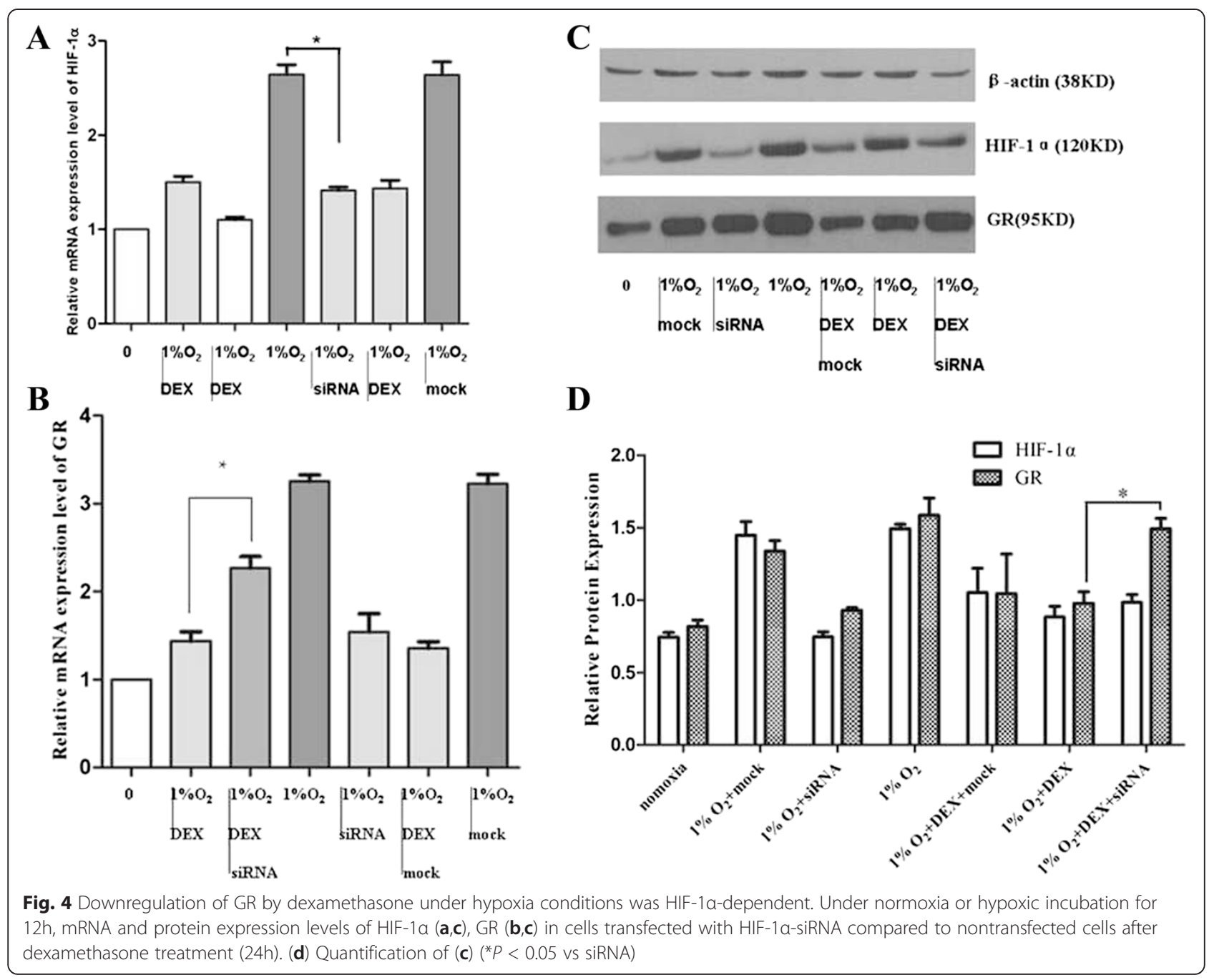

apoptosis compared with that of the mock and hypoxia groups. Thus, we conclude that HIF- $1 \alpha$ can protect AtT20 cells from hypoxia-induced apoptosis. Under normoxic conditions, dexamethasone (10 nM or $100 \mathrm{nM})$ increased mRNA and protein expression levels of HIF- $1 \alpha$, but suppressed HIF- $1 \alpha$ expression under hypoxic conditions. GR expression was upregulated under hypoxic conditions due to increased HIF-1 $\alpha$ mRNA and protein levels. Dexamethasone exhibited a stronger suppression of GR expression in hypoxia than in normoxia. Downregulation of GR by dexamethasone was greatly improved in cells transfected with HIF- $1 \alpha$ siRNA under hypoxic conditions, implying that dexamethasone-mediated suppression of GR may be HIF-1 $\alpha$ dependent.

Whether hypoxia induces a pro- or antiapoptotic response remains unclear [15]. There are published studies in support of both viewpoints. Hypoxia has been shown to indirectly produce a proapoptotic effect by upregulating the expression of Bcl-2 family members, or by associating with and/or stabilizing these proteins [16-19]. However,
HIF-1 $\alpha$ has also been proposed to have a protective role, limiting hypoxia-induced apoptosis [20-23]. In this regard, pancreatic cancer cell lines that constitutively express HIF$1 \alpha$ are more resistant to apoptosis induced by hypoxia compared to similar cell lines that lack constitutive expression of HIF-1 $\alpha$ [24]. Further evidence supporting an antiapoptotic role for HIF- $1 \alpha$ is demonstrated by the finding that a neutralising monoclonal antibody against vascular endothelial growth factor (VEGF), the major transcriptional target of HIF- $1 \alpha$, blocks the antiapoptotic effects of hypoxia in HepG2 cells [25]. Yoshida et al. [26] employed microarray analysis to study HIF- $1 \alpha$ in the nonfunctional human pituitary adenoma cell line, HP-75, and found that HIF- $1 \alpha$ downregulated caspase-10. This finding is consistent with our results, showing that hypoxia-induced HIF-1 $\alpha$ increased the growth and proliferation of AtT-20 cells partly due to the role of HIF- $1 \alpha$ as an inhibitor of hypoxia-induced apoptosis.

Cross-talk between glucocorticoid and hypoxiadependent signalling cascades has been demonstrated in several studies. The first evidence of an interaction 
between HIF-1 $\alpha$ and GR was provided by Kodama et al. [9], who found that ligand-dependent activation of GR enhanced hypoxia-dependent gene expression and hypoxia response element (HRE) activity in HeLa cells. Leonard et al. [10] revealed that GR is transcriptionally upregulated by hypoxia in human renal proximal tubular epithelial cells. Further, hypoxic upregulation of GR was confirmed at the level of promoter activity, mRNA, and protein expression, consistent with our results. Wagner et al. [11] demonstrated a dexamethasone-mediated inhibition of HIF- $1 \alpha$ target gene expression in hypoxic HEPG2 cells. Furthermore, they showed retention of HIF- $1 \alpha$ in the cytoplasm, suggesting a block in nuclear import. Gaber et al. [27] found a clear inhibition of HIF-1 $\alpha$ protein expression, which resulted in reduced HIF-1 target gene expression, including VEGF. Interestingly, they also found that PHD1 was regulated in a similar manner as VEGF. Del Peso et al. [28] showed that PHD1 was upregulated by hypoxia in HeLa cells. Therefore, we conclude that the interaction between the glucocorticoid- and hypoxia-dependent signalling cascades is significant as well as varied. These data reflect the complexity and context-specific alterations associated with the differential activation of these cascades in complex tissue microenvironments.

Our study demonstrated that GR expression levels were upregulated by HIF- $1 \alpha$ under hypoxic conditions. However, treatment with dexamethasone caused these levels to decrease in a hypoxia-dependent manner. The results clearly indicate that HIF- $1 \alpha$ may play a role in the downregulation of GR expression by dexamethasone, which was further confirmed by transfection of HIF- $1 \alpha$ siRNA. However, additional experimental evidence is needed to determine the underlying mechanism involved. We are now attempting to employ a luciferase assay, EMSA, and coimmunoprecipitation to clarify the mechanism, and an ACTH pituitary adenoma animal model is under construction.

The current study has profound clinical importance and supports a therapeutic role for HIF- $1 \alpha$ in ACTH pituitary adenoma due to its antiapoptotic effects and downregulation of GR. Therefore, we suggest that siRNA targeting HIF- $1 \alpha$ may have potential therapeutic value in treating ACTH pituitary adenoma.

\section{Conclusions}

Our present data demonstrate an increased cell proliferation index in AtT-20 cell lines after hypoxia exposure through the induction of HIF- $1 \alpha$ expression, which played a crucial role in protecting AtT-20 cells from hypoxiainduced apoptosis. HIF-1 $\alpha$ upregulated GR expression at both mRNA and protein levels. We also found that the downregulation of GR by dexamethasone in hypoxic conditions is probably due to the suppression of HIF- $1 \alpha$ by dexamethasone, which means that GR downregulation by dexamethasone is HIF- $1 \alpha$ dependent.

\section{Abbreviations}

HIF-1a: Hypoxia inducible factor-1; ACTH: Adrenocorticotrop(h)ic hormone; VEGF: Vascular endothelial growth factor; FITC: Fluorescein isothiocyanate; TUNEL: TdT-mediated dUTP-biotin nick end labeling; SDS-PAGE: Sodium dodecyl sulfate polyacrylamide gel electrophoresis.

\section{Competing interests}

The authors declare that they have no competing interests.

\section{Authors' contributions}

QQ, JY and HLH participated in patient selection/sample collections, laboratory measurements and data analysis. HGH participated in the study design and in the supervision of apoptosis detection. DXH and LYC participated in patient selection, study design and laboratory evaluations. ZCR participated in study design and laboratory measurements, supervised data collection and analysis and wrote the manuscript. All authors revised the manuscript. All authors read and approved the final manuscript.

\section{Acknowledgments}

This work was generously supported by Shanghai Municipal Natural Science Foundation (14ZR1413800), Shanghai Municipal Health Bureau Project (201440383) and Foundation for Youths of Changzheng Hospital

\section{(2012CZQN05)}

\section{Author details}

${ }^{1}$ Department of Neurosurgery, Shanghai Changzheng Hospital, Second Military Medical University, No. 415, Feng-Yang Road, Shanghai 200003, China. ${ }^{2}$ Department of Neurology, Huadong Hospital, Fudan University, Shanghai 200040, China. ${ }^{3}$ Department of Cardiology, Ren Ji Hospital, School of Medicine, Shanghai Jiao Tong University, Shanghai 200127, China.

Received: 14 November 2014 Accepted: 20 April 2015

Published online: 23 May 2015

\section{References}

1. Cerman J, Cap J, Marekova M, Nemecek S, Marek J, Rudolf E, et al. The role of apoptosis in pituitary adenomas in the field of conventionally used therapeutic approaches. Ann N Y Acad Sci. 2003;1010:520-4.

2. Kristof RA, Aliashkevich AF, Hans V, Haun D, Meyer B, Thees C, et al. The regional oxygen saturation of pituitary adenomas is lower than that of the pituitary gland: microspectrophotometric study with potential clinical implications. Neurosurgery. 2003;53:880-5. discussion 885-886.

3. Sun L, Hao Y, An R, Li H, Xi C, Shen G. Overexpression of Rcan1-1L inhibits hypoxia-induced cell apoptosis through induction of mitophagy. Mol Cells. 2014;5. doi: 10.14348 .

4. Kapranos N, Kontogeorgos G, Horvath E, Kovacs K. Morphology, molecular regulation and significance of apoptosis in pituitary adenomas. Front Horm Res. 2004;32:217-34.

5. Manalo DJ, Rowan A, Lavoie T, Natarajan L, Kelly BD, Ye SQ, et al. Transcriptional regulation of vascular endothelial cell responses to hypoxia by HIF-1. Blood. 2005;105:659-69.

6. Vidal S, Horvath E, Kovacs K, Kuroki T, Lloyd RV, Scheithauer BW. Expression of hypoxia-inducible factor-1alpha(HIF-1alpha) in pituitary tumours. Histol Histopatho. 2003;118:679-86.

7. Long Q, Fan C, Kai W, Luo Q, Xin W, Wang P, et al. Hypoxia inducible factor-1a expression is associated with hippocampal apoptosis during epileptogenesis. Brain Res. 2014;ii: S0006-8993(14)01249-9. doi: 10.1016.

8. Hellwig-Buergel, Wagner TA, Jelkmann W. Biology of hypoxia:the role of oxygen sensing in development, normal function and disease. In: Keystone Symposium 2004. 2004. p. 25-30.

9. Kodama T, Shimizu N, Yoshikawa N, Makino Y, Ouchida R, Okamoto K, et al. Role of the glucocorticoid receptor for regulation of hypoxia-dependent gene expression. J Biol Chem. 2003;278:33384.

10. Leonard MO, Godson C, Brady HR, Taylor CT. Potentiation of glucocorticoid activity in hypoxia through induction of the glucocorticoid receptor. J Immunol. 2005;174:2250-7. 
11. Wagner AE, Huck G, Stiehl DP, Jelkmann W, Hellwig-Bürgel T. Dexamethasone impairs hypoxia-inducible factor-1 function. Biochem Biophys Res Commun. 2008;372:336-40

12. Zhang J, Song LP, Huang Y, Zhao Q, Zhao KW, Chen GQ. Accumulation of hypoxia-inducible factor-1 alpha protein and its role in the differentiation of myeloid leukemic cells induced by all-trans retinoic acid. Haematologica. 2008;93:1480-7.

13. Yang $L$, Jiang $Y$, Wu SF, Zhou MY, Wu YL, Chen GQ. CCAAT/enhancerbinding protein alpha antagonizes transcriptional activity of hypoxia-inducible factor 1 alpha with direct protein-protein interaction. Carcinogenesis. 2008;29:291-8.

14. Simpson DA, Feeney S, Boyle C, Stitt AW. Retinal VEGF mRNA measured by SYBR green I fluorescence: A versatile approach to quantitative PCR. Mol Vis. 2000;6:178-83.

15. Achison M, Hupp TR. Hypoxia attenuates the p53 response to cellular damage. Oncogene. 2003;22:3431-40.

16. Ibrahim AE, Pickering RM, Gawne-Cain ML, King S, Lees PD, Ellison DW. Indices of apoptosis and proliferation as potential prognostic markers in non-functioning pituitary adenomas. Clin Neuropathol. 2004;23:8-15.

17. Kothari S, Cizeau J, McMillan-Ward E, Israels SJ, Bailes M, Ens K, et al. BNIP3 plays a role in hypoxic cell death in human epithelial cells that is inhibited by growth factors EGF and IGF. Oncogene. 2003;22:4734-44.

18. Koshiji M, Kageyama Y, Pete EA, Horikawa I, Barrett JC, Huang LE. HIF-1alpha induces cell cycle arrest by functionally counteracting. Myc Embo J. 2004;23:1949-56

19. Li A, Sun X, Ni Y, Chen X, Guo A. HIF-1a Involves in Neuronal Apoptosis after Traumatic Brain Injury in Adult Rats. J Mol Neurosci. 2013;51:1052-62.

20. Akakura N, Kobayashi M, Horiuchi I, Suzuki A, Wang J, Chen J, et al. Constitutive expression of hypoxia-inducible factor-1alpha renders pancreatic cancer cells resistant to apoptosis induced by hypoxia and nutrient deprivation. Cancer Res. 2001:61:6548-54.

21. Li DW, Dong P, Wang F, Chen XW, Xu CZ, Zhou L. Hypoxia Induced Multidrug Resistance of Laryngeal Cancer Cells via Hypoxia-inducible Factor-1a. Asian Pac J Cancer Prev. 2013;14:4853-8.

22. Tian X, Wang W, Zhang Q, Zhao L, Wei J, Xing H, et al. Hypoxia-inducible factor-1a enhances the malignant phenotype of multicellular spheroid HeLa cells in vitro. Oncol Lett. 2010;1:893-7.

23. Yao L, Nie X, Shi S, Song S, Hao X, Li S, et al. Reciprocal regulation of HIF-1a and 15-LO/15-HETE promotes anti-apoptosis process in pulmonary artery smooth muscle cells during hypoxia. Prostaglandins Other Lipid Mediat. 2012:99:96-106.

24. Moritz W, Meier F, Stroka DM, Giuliani M, Kugelmeier $P$, Nett PC, et al. Apoptosis in hypoxic human pancreatic islets correlates with HIF-1alpha expression. Faseb J. 2002;16:745-7.

25. Baek JH, Jang JE, Kang CM, Chung HY, Kim ND, Kim KW. Hypoxia-induced VEGF enhances tumor survivability via suppression of serum deprivationinduced apoptosis. Oncogene. 2000;19:4621-31.

26. Yoshida D, Kim K, Noha M, Teramoto A. Anti-apoptotic action by hypoxia inducible factor 1-alpha in human pituitary adenoma cell line, HP-75 in hypoxic condition. J Neurooncol. 2006;78:217-25.

27. Gaber T, Schellmann S, Erekul KB, Fangradt M, Tykwinska K, Hahne M, et al. Macrophage Migration Inhibitory Factor Counterregulates DexamethasoneMediated Suppression of Hypoxia-Inducible Factor-1a Function and Differentially Influences Human CD4+ T Cell Proliferation under Hypoxia. J Immunol. 2011:186:764-74.

28. del Peso L, Castellanos MC, Temes E, Martin-Puig S, Cuevas Y, Olmos G, et al. The von Hippel Lindau/hypoxia-inducible factor (HIF) pathway regulates the transcription of the HIF-proline hydroxylase genes in response to low oxygen. J Biol Chem. 2003:278:48690-5.

\section{Submit your next manuscript to BioMed Central and take full advantage of:}

- Convenient online submission

- Thorough peer review

- No space constraints or color figure charges

- Immediate publication on acceptance

- Inclusion in PubMed, CAS, Scopus and Google Scholar

- Research which is freely available for redistribution 